\title{
CONSUMER INVOLVEMENT IN THE PURCHASING PROCESS: CONSCIOUSNESS OF THE CHOICE
}

\author{
Laima Jeseviciute-Ufartiene \\ Kauno Kolegija University of Applied Science, Kaunas, Lithuania, laima.jeseviciute@go.kauko.lt
}

\begin{abstract}
Research purpose. Consumer is becoming demanded one in the purchasing process. Thus, consumer behaviour analyses thinking about his or her involvement in the purchase process could be a solution for marketers. This article concentrates on the consumer's choice of food products in the purchase process because the author is interested to clarify the connection amongst choice, purchase and wasting of food. The research purpose is to evaluate the consumer's consciousness in choosing food product in the purchase process.
\end{abstract}

Design/Methodology/Approach. Quantitative method using questionnaire was applied to 643 respondents whilst implementing formulated aim. Cronbach's alpha analyses of 35 items (0.870) showed reliability of the research.

Findings. The research results indicated that consumer in the food purchase process is low conscious because he or she does not understand that he or she is buying more than what he or she needs and thus some of his or her purchase becomes waste. Consumer's consciousness could be seen in the consumer's lifestyle such as preferences for homemade food.

Originality/Value/Practical implications. The research results could be used in practice and science. Foodproducing companies might use some research results making their packaging solutions. The research results could give incites for scientists for future research.

Keywords: Consumer; Involvement; Purchasing process; Customer; Consciousness.

JEL codes: M310; M370.

\section{Introduction}

Relevance of the research. Consumer is becoming demanded one in the purchasing process. Thus, consumer behaviour analyses thinking about his or her involvement in the purchase process could be a solution for marketers. Scientist in different countries analysed different consumer's behaviour aspects. Scientists have been researching consumer's behaviour depending on hedonic and utilitarian aspects (Lee et al. 2013; Filho, 2012) and have been trying to define how consumer decides and what kind of profile, values and benefits influences their decision to make purchase. Other surveys analysed consumer's decisions, consciousness and preference regarding green purchases (Schuitema \& de Groot, 2015). Some researches (Filho \& Brito, 2017) analysed rational or emotional decision of consumer choosing eco-friendly green technologies.

Regarding food market, scientists analysed consumer behaviour in choosing certain products such as olive oil (Ghali, 2019), yogurt (Sarti et al. 2018; Kytö et al. 2019), protein quarks (Kytö et al. 2019), and technologies (Filho \& Brito, 2017). Some researches indicate (Kytö et al. 2019) that package picture instore, simulations in-store and tasting at home influence to intentions to purchase product. Lithuanian case of green purchase research (Liobikiene et al. 2017) was more focused on external factors such as price, green purchase and environment friendly behaviour than on internal factors such as organic foods or healthy nutrition. However, this article concentrates on the consumer's choice of food products in the purchase process because the author is interested to clarify the connection amongst choice, purchase and wastage of food. Another important difference from this research is that Lithuanian case (Liobikiene et al. 2017) was analysed using data collected by Eurobarometer but the author of this article conducted this survey by herself. The research of this article is not based on certain food group but is focused on consumer's behaviour according to his or her lifestyle whilst choosing cook at home or purchasing semifinished products in the store that is directly related with consumer's consciousness to the healthy food. 
The research purpose is to evaluate consumer consciousness in choosing food product in the purchase process. Two main tasks are chosen for research purpose implementation:

- To determine how consumer's involvement in the purchase process is related with lifestyle activities such as cooking at home, buying semi-finished products or purchasing food cooked at shop;

- To find out how consumer's involvement is related with eco/green purchase, importance of food product country of origin and food wastage.

The research purpose has intention to search for prevalence of consumer behaviour. Thus, quantitative method using questionnaire was applied to 643 respondents whilst implementing the formulated aim. Cronbach's alpha analyses of 35 items (0.870) showed the reliability of the research.

The research results indicated that consumer in the food purchase process is low consciousness because he or she does not understand that he or she is buying more than what he or she needs and thus some of his or her purchase becomes waste. Consumer's consciousness could be seen in the consumer's lifestyle such as preferences for home-made food.

\section{Literature Review}

Consumer's consciousness. Consumer consciousness in choosing food products in the purchase process could be explained in terms of consumer's values related to their lifestyle and influencing their purchase process. Nowadays, consumer is under pressure of group behaviour because collectivists are more interested in a healthy label (Sarti et al. 2018). Recent industrial survey reports show that $90 \%$ of online shoppers read consumer product reviews and $83 \%$ reported that their purchase decisions are directly affected by the reviews (Weisstein et al. 2017). However, consumer is influenced by great amounts of information on the food labels and it makes difficult for consumers to make consciousness in food purchasing decisions (Montandon et al. 2017).

Differences in consumptions exist amongst different kinds of products. For example, research of technological products indicates (Filho \& Brito, 2017) that if a consumer is becoming a part of green perception groups, his or her utilitarian values are higher than the hedonic ones. Another example could be given from food endorsement programmes. Nutritional endorsement programmes have been applied to raise consumer's consciousness about the role of food to healthy lifestyle, and according to some research (Montandon et al. 2017), these programmes do play a role in consumer's decision-making in the purchasing process. This research is focused on food consumption decisions. Thus, consumers' consciousness related to healthy nutrition and sustainability is analysed further.

Sustainability and health-related information on the labels is supplied for consumers to raise their consciousness of healthy nutrition (Nuttavuthisit \& Thøgersen, 2017). This is how government and other stakeholders are endorsing products to credence the goods (Atkinson \& Rosenthal, 2014; Sarti et al. 2018). Consumers frequently self-report having sustainability or health-related preferences (Ha \& Janda, 2012; Sarti et al. 2018). Furthermore, consumers are diverse because they might choose special products based on the quality of a single item, and also in some cases, they prefer products with the diversity of use and the number of benefits, even if the base product is inferior in quality compared with an alternative (Filho \& Brito, 2017). Consumers are purchasing products because of values such as their enjoyment and social status (Schuitema \& de Groot, 2015), their interests and preferences (Filho \& Brito, 2017). However, consumer's self-reports and actual behaviour might be different because of information, awareness and personal capabilities depended on their lifestyle (Chekima et al. 2017; Fischer et al. 2017; Sarti et al. 2018). Consumers' perception of sustainability and healthy food could be based on individuals' motivations (Prothero et al. 2010), socio-demographics (Verain et al. 2012), cognitions (Verain et al. 2012) and lifestyles (Sarti et al. 2018).

Research indicates (Popa et al. 2019) that consumer perceive organic foods as safe and nutritious (Ghali, 2019). The consumers prefer to acquire regional organic foods (Lorenz et al. 2015). They believe such food to be more reliable, fresh and better tasting (Costanigro et al. 2014). Consumers are becoming more interested in the environment and human health (Laureti \& Benedetti, 2018; Ghali, 2019). Consumers' 
intentions to buy organic product depended on the country of origin of the product (Lorenz et al., 2015; Rahman, 2018; Ghali, 2019).

Consumers' involvement. Involvement could be described as consumer's perception of product importance (Zaichkowsky, 1985) that is influenced by his or her values and interests in long term (Rahman, 2018; Ghali, 2019). Involvement with the product could differ from low to high (Park \& Keil, 2019). Low involvement means minimum effort from consumer, and oppositely, high involvement is related with consumers' intentions of searching for various information and careful considerations and comparison of different brands concerning motivation and values (Handriana \& Wisandiko, 2017; Kim et al., 2019) in the purchase process.

Consumers' purchase process depends on their reaction to different stimuli under different involvement cases (Montandon et al. 2017). Consumer involvement with different levels is related with consumer's purchase purpose (Xia \& Monroe, 2009). As some scientists observed (Weisstein et al. 2017), goaldirected consumers give preference to utilitarian benefits or value, prepare shopping plan and trust on extrinsic motives for their choices. Oppositely, experiential consumers concentrate on hedonic value and internal motives. Thus, consumer's involvement with the product could be understood as important part of consumer's decision processes during supermarket visits (Montandon et al. 2017). Taking in account the theoretical consumptions about consumer's consciousness, it could be seen that consumer's involvement depends on consumer's interests or lifestyle and values. Consumer's lifestyle determines priorities of purchasing choice (Sarti et al. 2018), and it in some way relates with consumer's consciousness.

It could be expected that consumers would use a greater range of product choice factors if they were highly involved with a product (Montandon et al. 2017). Product choice might depend on country of origin, health claims, product endorsements, quality certification, appearance of the food, consumer's claims, health endorsements and green or eco aspects of production (Montandon et al. 2017). The results of the research (Montandon et al. 2017) showed that for low-involvement purchase, brand played the most important role in consumer decision-making (55.1\%), followed by price (26.6\%) and the presence of the health endorsement (18.3\%) relative to each other. In consumers' decision-making preferences for the high-involvement product (Montandon et al. 2017), price was determined to have played the most important role $(50.72 \%)$, followed by brand $(26.84 \%)$ and the presence of the health endorsement $(22.43 \%)$. Thus, there could be assumed that low involvement is related with external influence such as brand rather than health endorsement, which is more inherent for high involvement. Perception of health endorsement could be understood as quality of food for consumer, and it could be counted as consumer's consciousness in the purchase process.

Consumers with no experience or low positive attitude about green attributes could have a positive perception about the convergence and even a higher desire to purchase a product with many attributes, differently from consumers with a negative attitude (Filho \& Brito, 2017). Thus, products that qualify for these labels typically must meet externally determined criteria such as third-party certification (Darnall \& Potoski, 2017; Sarti et al. 2018).

Some research (Sarti et al., 2018) focuses on consumers' macro/micro motivations, demographics, cognition and lifestyles. Studies suggest (Verain et al. 2012) that product label influences the purchase of consumer described by demographics such as individual's age, gender, income, education, occupation, social class and place of residence. Even more, consumer's cognition of healthy food is related with labelled products (Verain et al. 2012). Thus, external factors should be analysed. External factors influencing consumer's involvement in the purchase process could be pricing, branding, shape and size of the packaging, country of origin, health claims, sustainability claims, product endorsements, quality certification, look and texture of the food, production claims and health endorsements (Montandon et al. 2017). Accordingly, consumer's buying motives (Hüttel et al. 2018) are micro such as supporting local businesses or individual concerns related to personal or family health and macro such as societal and environmental concern (Kareklas et al. 2014). Consumers are interested in information such as the origin of the product (Feldmann \& Hamm, 2015). This research is focusing on micro-level motives such as related to organic foods or healthy nutrition, sometimes-signed eco or green. As consumer perceive an organic labelled food as being safer and healthier (Kareklas et al. 2014), for 
this research, it will serve as consumer's consciousness in choosing the healthy food product in the purchase process.

Sustainable consumption. Sustainable consumption has been understood as consumers' usage of goods and services responding to basic needs. This consumption brings a better quality of life whilst minimising the use of natural resources and toxic materials as well as the emissions of waste and pollutants over the life cycle of the service or product, saving the world for future generations (Kilbourne et al. 1997; Joshi \& Rahman, 2019).

The results indicate that the drive for environmental responsibility, spirituality and perceived consumer effectiveness are the key psychological determinants of consumers' sustainable purchase decisions (Joshi \& Rahman, 2019). According to Italian market research (Sarti et al. 2018), just 7\% of all market (27.5\% collectivists, $10.0 \%$ individualists and $3.6 \%$ indifferent) are interested in the health-related labels and sustainability of purchased product.

Sustainable purchase is important for the reduction of environmental degradation (Biswas \& Roy, 2015) and studies (Liobikiene et al. 2017; Cerri et al. 2018; Nguyen et al. 2018; Joshi \& Rahman, 2019) show importance to endorse sustainable purchase behaviour. Consumers tend to ignore the outcomes of their purchase results (Liobikiene et al. 2017; Joshi \& Rahman, 2019), for example, wasting food and buying larger amount of food than actually needed. This inequality of consumer's perception and actual behaviour about sustainable purchase is called attitude-behaviour gap (Padel \& Foster, 2005).

This study is particularly interested just in eco or green aspect and country of origin as quality of product with high involvement and external factors such as commercial influence to bigger amount of purchasing products. At the same time, this research focuses on sustainable consumption factors such as consciousness in choosing the amount of food and food wastage.

\section{Methodology}

Consumer's consciousness in choosing food products in the purchase process was researched using quantitative questionnaire. This type of survey is frequently used to find out the prevalence of some consumers' behaviour factors (Montandon et al. 2017). Regarding determined purpose of this article, two research questions are raised:

- To determine how consumer's involvement in the purchase process is related with lifestyle activities such as cooking at home, buying semi-finished products or purchasing food cooked at shop;

- To find out how consumer's involvement is related with eco/green purchase, importance of food product country of origin and food wastage.

The structure of the research is shown in Figure 1. The research questions were formed using operationalised thoughts of literature review:

- Socio-demographics (Verain et al. 2012);

- Consumer's involvement (Montandon et al. 2017);

- Consumer's lifestyle activities (Sarti et al. 2018) such as cooking at home, buying semi-finished products or purchasing food cooked at shop as goal-related motivation (Weisstein et al. 2017) and family-related motivation (Kareklas et al. 2014);

- Eco/green purchase, importance of food product country of origin (Feldmann \& Hamm, 2015; Lorenz et al., 2015; Rahman, 2018; Ghali, 2019), external factors from marketing (Montandon et al. 2017) and food wastage (Joshi \& Rahman, 2019).

Research questions were formed using Likert scale from 1 to 5, where 1 means 'totally disagree', 2 'disagree', 3 'partly agree', 4 'agree' and 5 'totally agree'. The same scale was used to identify the frequency of purchase, where 1 means 'never', 2 'less than once a week', 3 'once a week', 4 'every second day' and 5 'every day'.

People who are shopping for food in their life were selected as the research's respondents. This research is not dividing respondents who are regularly shopping in the store and those who do online shopping. 
Accordingly, 385 sample size of respondents were calculated using 2,808,901 population in Lithuania (Statistics, 2018), 95\% of confidence level, 5\% of error level and 50\% of response distribution (Raosoft, 2019).

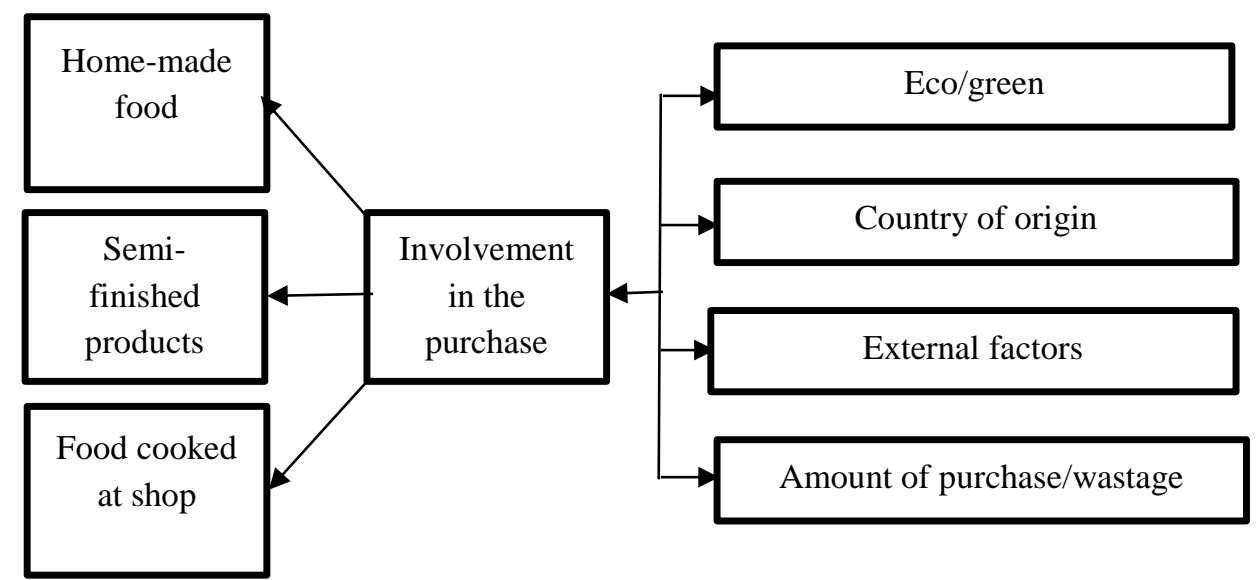

Fig. 1. Structure of the research (Source: made by the author)

The research was conducted in 2018 autumn together with the help of students from the Department of Business, Kauno Kolegija University of Applied Science. Students were printing, distributing and collecting the filled questionnaires. The sample consists of 643 filled questionnaires. Data were analysed using SPSS program and methods such as descriptive statistics and Spearman correlation were used for reliability analyses. Cronbach's alpha analyses of 35 items ( 0.870$)$ showed the reliability of the research.

Demographic data of the research (Table 1) show that $64.2 \%$ of research respondents were women and $36.5 \%$ were men. The research data give information about respondents who are Lithuanians with low or average income. These kinds of incomes cover about $60 \%$ of Lithuanian working people (Statistics, 2019). Thus, research data are consistent with Lithuanian situation. About 5.8\% of the research respondents were with basic education, $41.7 \%$ with secondary education, $28.5 \%$ with higher education and $22.7 \%$ with university education.

Table 1. Demographic data of the research (Source: author's compilation)

\begin{tabular}{|r|c|c|c|c|c|c|c|c|}
\hline \multicolumn{2}{|c|}{ Gender } & \multicolumn{3}{|c|}{ Incomes } & \multicolumn{4}{c|}{ Education } \\
\hline Female & Male & $\begin{array}{c}\text { Till } 400 \\
\text { Euro }\end{array}$ & $\begin{array}{c}401-800 \\
\text { Euro }\end{array}$ & $\begin{array}{c}\text { More than } 801 \\
\text { Euro }\end{array}$ & Basic & Secondary & Higher & University \\
\hline 64.2 & 36.5 & 36.5 & 40.7 & 21.6 & 5.8 & 41.7 & 28.5 & 22.7 \\
\hline
\end{tabular}

\section{Results}

The results indicate low involvement of respondents in the food purchase process. Data in Table 2 shows that consumer is hardly paying attention to the information on the product's label (3.00). The biggest involvement of consumer is shown just with checking the date of expiry (4.02) or checking for product condition if this product is on sale (3.55). 
Table 2. Consumer's involvement into food purchase (Source: author's compilation)

\begin{tabular}{|c|c|c|c|}
\hline Research scale & Mean & StDev & Skewness \\
\hline Consumer is reading information on products' label & 3.00 & 1.189 & -0.033 \\
\hline Consumer is checking the date of expiry & 4.02 & 1.155 & -1.158 \\
\hline Checking for product condition during sales & 3.49 & 1.195 & -0.529 \\
\hline Checking the condition of product package & 3.55 & 1.261 & -0.639 \\
\hline Checking for mistakes in the receipt & 3.06 & 1.324 & -0.118 \\
\hline
\end{tabular}

Regarding complied data in Table 2, 'consumer is reading information on product's label' was taken as indicator of low involvement. This choice was made after the evaluation of correlation with other researched factors. It showed stronger correlation with other items shown in Table 2.

Data in Table 3 show that low or high involvement in the purchase process is weakly but statistically significantly correlating with lifestyle such as cooking at home. Very poor and negative correlation is indicated with consumer's lifestyle such as buying cooked food. Analysing such results could state that consumer's lifestyle is related with purchasing involvement but deeper analyses is required; thus, mean value comparison analysis is provided.

Table 3. Involvement into lifestyle activities such as cooking at home, buying semi-finished products or purchasing food cooked at shop (Source: author's compilation)

\begin{tabular}{|c|c|c|}
\hline Spearman correlation between: & $\begin{array}{c}\text { Consumer is reading information } \\
\text { on products' label } \\
\text { (low involvement) }\end{array}$ & $\begin{array}{c}\text { Consumer is checking the date } \\
\text { of expiry } \\
\text { (high involvement) }\end{array}$ \\
\hline Cooking food at home & $0.250^{* *}$ & $0.303^{* *}$ \\
\hline Buying semi-finished food products & 0.008 & $-0.206^{* *}$ \\
\hline Buying food cooked at shop & $-0.122^{* *}$ & $-0.133^{* *}$ \\
\hline
\end{tabular}

Note: 643 respondents; $* \mathrm{p}<0.05 ; * * \mathrm{p}<0.01$ level.

The results show that those consumers who read information on the product's label care about healthy nutrition (mean value of totally agree is 3.88 in Table 4), include lots of vegetables and fruits in their nutrition (3.72 in Table 4) and intend to buy healthy food (4.06 in Table 4). Thus, consumers' interested into healthy lifestyle are making them higher involved in the purchase process.

Table 4. Consumers' involvement in the healthy food (Source: author's compilation)

\begin{tabular}{|c|c|c|c|c|c|c|c|c|c|c|c|}
\hline \multicolumn{7}{|c|}{ Consumer is reading information on products' label } \\
\hline $\begin{array}{c}\text { Consumer } \\
\text { care about } \\
\text { healthy } \\
\text { nutrition }\end{array}$ & Mean & $\mathbf{N}$ & StDev & $\begin{array}{c}\text { Consumer include } \\
\text { lots of vegetables } \\
\text { and fruits in his } \\
\text { nutrition }\end{array}$ & Mean & $\mathbf{N}$ & StDev & $\begin{array}{c}\text { Consumer } \\
\text { is buying } \\
\text { healthy } \\
\text { food }\end{array}$ & Mean & $\mathbf{N}$ & StDev \\
\hline $\begin{array}{c}\text { Totally } \\
\text { disagree }\end{array}$ & 1.82 & 22 & 1.259 & Totally disagree & 2.66 & 29 & 1.289 & $\begin{array}{c}\text { Totally } \\
\text { disagree }\end{array}$ & 2.09 & 33 & 1.071 \\
\hline Disagree & 2.41 & 75 & 1.015 & Disagree & 2.63 & 94 & 1.057 & Disagree & 2.68 & 117 & 1.056 \\
\hline $\begin{array}{c}\text { Partly } \\
\text { agree }\end{array}$ & 2.75 & 251 & 0.941 & Partly agree & 2.77 & 205 & 1.077 & $\begin{array}{c}\text { Partly } \\
\text { agree }\end{array}$ & 2.79 & 254 & 0.990 \\
\hline Agree & 3.31 & 185 & 1.026 & Agree & 3.09 & 178 & 1.043 & Agree & 3.34 & 149 & 1.144 \\
\hline $\begin{array}{c}\text { Totally } \\
\text { agree }\end{array}$ & 3.88 & 104 & 1.244 & Totally agree & 3.72 & 129 & 1.179 & $\begin{array}{c}\text { Totally } \\
\text { agree }\end{array}$ & 4.06 & 82 & 1.010 \\
\hline
\end{tabular}


Analyses of consumer's involvement in the country of origin shows that those consumers who are more interested in the origin of the product (totally agree mean value of 3.9 in Table 5) and chooses to consume Lithuanian product (3.94 in Table 5) are more involved in the purchase process. Spearman correlation analyses is used for analysing the consumer's involvement with consumer's care about country of origin $(0.452, p<0.01)$ and consumer's choice for Lithuanian product $(0.420, p<0.01)$. This medium-strength but statistically important correlation confirms that consumers' involvement is higher if we assume that the consumers' interests are related with their lifestyle factors.

Table 5. Consumers' involvement in the country of origin (Source: author's compilation)

\begin{tabular}{|c|c|c|c|c|c|c|c|}
\hline \multicolumn{7}{|c|}{ Consumer is reading information on products' label } \\
\hline $\begin{array}{c}\text { Consumer cares about } \\
\text { country of origin }\end{array}$ & Mean & $\mathbf{N}$ & StDev & $\begin{array}{c}\text { Consumer chooses } \\
\text { Lithuanian product }\end{array}$ & Mean & N & StDev \\
\hline Totally disagree & 2.15 & 74 & 1.143 & Totally disagree & 2.07 & 56 & 1.189 \\
\hline Disagree & 2.66 & 167 & 0.916 & Disagree & 2.66 & 143 & 1.027 \\
\hline Partly agree & 3.01 & 213 & 0.988 & Partly agree & 2.99 & 261 & 0.977 \\
\hline Agree & 3.66 & 119 & 1.061 & Agree & 3.54 & 108 & 1.131 \\
\hline Totally agree & 3.90 & 60 & 1.337 & Totally agree & 3.94 & 64 & 1.180 \\
\hline
\end{tabular}

Consumers' involvement into the purchase process regarding external factors such as advertisement (discounts or sales) was analysed. Actually, data in Table 6 show that consumers are not buying more because of discount or consumers are not more involved in the purchase process because they are checking for sales' adverts before shopping or because consumer are taking the advert journal before leaving the shopping place.

Table 6. Consumers' involvement in the purchase regarding external factors (Source: author's compilation)

\begin{tabular}{|c|c|c|c|c|c|c|c|c|c|c|c|}
\hline \multicolumn{12}{|c|}{ Consumer is reading information on products' label } \\
\hline $\begin{array}{l}\text { Consumer } \\
\text { usually is } \\
\text { buying more } \\
\text { products } \\
\text { because of } \\
\text { advertising }\end{array}$ & Mean & $\mathbf{N}$ & StDev & $\begin{array}{c}\text { Consumer } \\
\text { is checking } \\
\text { for sales' } \\
\text { adverts } \\
\text { before } \\
\text { shopping }\end{array}$ & Mean & $\mathbf{N}$ & StDev & $\begin{array}{c}\text { Consumer } \\
\text { takes } \\
\text { advert } \\
\text { journal } \\
\text { before } \\
\text { leaving the } \\
\text { shopping }\end{array}$ & Mean & $\mathbf{N}$ & StDev \\
\hline $\begin{array}{c}\text { Totally } \\
\text { disagree }\end{array}$ & 2.98 & 42 & 1.370 & $\begin{array}{c}\text { Totally } \\
\text { disagree }\end{array}$ & 3.04 & 74 & 1.297 & $\begin{array}{c}\text { Totally } \\
\text { disagree }\end{array}$ & 2.93 & 167 & 1.200 \\
\hline Disagree & 2.95 & 103 & 1.115 & Disagree & 2.81 & 141 & 1.127 & Disagree & 2.83 & 155 & 1.056 \\
\hline Partly agree & 2.97 & 194 & 1.115 & $\begin{array}{l}\text { Partly } \\
\text { agree }\end{array}$ & 2.98 & 173 & 1.048 & $\begin{array}{l}\text { Partly } \\
\text { agree }\end{array}$ & 3.10 & 149 & 1.101 \\
\hline Agree & 3.12 & 183 & 1.073 & Agree & 3.22 & 146 & 1.020 & Agree & 3.24 & 86 & 1.127 \\
\hline $\begin{array}{l}\text { Totally } \\
\text { agree }\end{array}$ & 3.05 & 115 & 1.317 & $\begin{array}{l}\text { Totally } \\
\text { agree }\end{array}$ & 3.10 & 102 & 1.404 & $\begin{array}{l}\text { Totally } \\
\text { agree }\end{array}$ & 3.22 & 79 & 1.374 \\
\hline
\end{tabular}

Spearman correlation analyses between respondents' statements about wasting of food with purchasing amount $(0.229, \mathrm{p}<0.01)$ and shopping frequency $(0.293, \mathrm{p}<0.01)$ show weak but statistically significant relation. Accordingly, the results (Table 7) show that those respondents who are buying more food than their family is able to consume, at least once a week and even more frequently, are wasting food. 
Table 7. Purchasing amounts and food wastage (Source: author's compilation)

\begin{tabular}{|c|c|c|c|c|c|c|c|c|c|c|c|}
\hline \multicolumn{7}{|c|}{ Consumer is buying more food than he/she/family is able to consume } & \multicolumn{3}{c|}{$\begin{array}{c}\text { Consumer's food shopping } \\
\text { frequency }\end{array}$} \\
\hline $\begin{array}{c}\text { Consumer's } \\
\text { food } \\
\text { shopping } \\
\text { frequency }\end{array}$ & Mean & $\mathbf{N}$ & StDev & $\begin{array}{c}\text { Wasting of } \\
\text { food } \\
\text { frequency }\end{array}$ & Mean & $\mathbf{N}$ & StDev & $\begin{array}{c}\text { Wasting of } \\
\text { food } \\
\text { frequency }\end{array}$ & Mean & N & StDev \\
\hline Never & 2.77 & 13 & 1.536 & Never & 2.68 & 88 & 1.402 & Never & 3.02 & 88 & 1.114 \\
\hline $\begin{array}{c}\text { Less than } \\
\text { once a week }\end{array}$ & 2.87 & 60 & 1.346 & $\begin{array}{c}\text { Less than } \\
\text { once a } \\
\text { week }\end{array}$ & 3.09 & 288 & 1.092 & $\begin{array}{c}\text { Less than } \\
\text { once a } \\
\text { week }\end{array}$ & 3.5 & 28 & 0.868 \\
\hline $\begin{array}{c}\text { Once a } \\
\text { week }\end{array}$ & 3.11 & 236 & 1.107 & $\begin{array}{c}\text { Once a } \\
\text { week }\end{array}$ & 3.38 & 175 & 1.163 & $\begin{array}{c}\text { Once a } \\
\text { week }\end{array}$ & 3.67 & $\begin{array}{c}17 \\
5\end{array}$ & 0.825 \\
\hline $\begin{array}{c}\text { Every } \\
\text { second day }\end{array}$ & 3.28 & 222 & 1.194 & $\begin{array}{c}\text { Every } \\
\text { second } \\
\text { day }\end{array}$ & 3.67 & 49 & 1.197 & $\begin{array}{c}\text { Every } \\
\text { second } \\
\text { day }\end{array}$ & 3.94 & 49 & 0.876 \\
\hline Every day & 3.32 & 103 & 1.23 & Every day & 3.42 & 31 & 1.177 & Every day & 3.97 & 31 & 1.169 \\
\hline
\end{tabular}

The results of this research (Table 8$)$ indicate weak $(0.221, p<0.01)$ but statistically significant Spearman correlation between consumers 'cooking at home' and 'caring about healthy nutrition'. At the same time, negative correlation is indicated between 'cooking at home' and buying semi-finished $(-0.275, \mathrm{p}<0.01)$ or cooked products in the shop $(-0.244, \mathrm{p}<0.01)$. These results show that cookingat-home consumers perceive homemade food as healthy nutrition and do not relate health with semifinished products. The results of this study allow assuming that cooking-at-home consumers are more consciousness consumer and more involved in the purchasing process than those buying semi-finished or cooked products.

Table 8. Lifestyle related with consumption of food and its wastage (Source: author's compilation)

\begin{tabular}{|c|c|c|c|}
\hline Spearman correlation between: & $\begin{array}{c}\text { Cooking at } \\
\text { home }\end{array}$ & $\begin{array}{c}\text { Buying semi- } \\
\text { finished } \\
\text { products }\end{array}$ & $\begin{array}{c}\text { Buying cooked food } \\
\text { in the shop }\end{array}$ \\
\hline $\begin{array}{c}\text { Consumer care about healthy nutrition } \\
\text { Consumer is buying more food than he/she/family is } \\
\text { able to consume }\end{array}$ & $0.221^{* *}$ & -0.036 & $-0.153^{* *}$ \\
\hline Consumer's food shopping frequency & 0.024 & $0.129^{* *}$ & $0.097^{*}$ \\
\hline Wasting of food frequency & 0.014 & $0.161^{* *}$ & $0.107^{* *}$ \\
\hline Cooking at home & 1.000 & $-0.275^{* *}$ & $-0.244^{* *}$ \\
\hline Buying semi-finished products & $-0.275^{* *}$ & 1.000 & $0.439^{* *}$ \\
\hline Buying cooked food in the shop & $-0.244^{* *}$ & $0.439^{* *}$ & 1,000 \\
\hline
\end{tabular}

Note: 643 respondents; $* \mathrm{p}<0.05 ; * * \mathrm{p}<0.01$ level.

\section{Conclusions}

The results obtained from this research are consistent with those of some researches, (Kytö et al. 2019) indicating that food consumptions are low involvement products. However, this research supplements past research by explaining that consumers' interests into healthy food are related with higher involvement in the food product purchase process. Thus, lifestyle studies are important for analysing consumers' involvement.

The results of this research is consistent with those of some other researches (Sarti et al. 2018), stating that consumer's involvement depends on consumer's interests or lifestyle and that consumer's lifestyle determines priorities of purchasing choice (Sarti et al. 2018). However, the results of this research specifically indicate consumer's lifestyle related with food consumption. The results state that cooking 
at home consumers are more consciousness consumer and more involved in the purchase process than those consumers who are buying semi-finished or cooked products.

The research results indicated that consumers of semi-finished products and cooked products in the shop are low conscious because they do not understand that they are buying more than what they needs and thus some of their purchase becomes waste. Consumer's consciousness could be seen in the consumer's lifestyle such as preferences for homemade food.

It should be mentioned that this research focused on Lithuanian consumers and their involvement into the purchase process, their consciousness in choosing healthy products and product amount and consequences regarding bought amounts of food such as wasting food. Deeper research could be made specifying the certain food groups such as grain, vegetables, fruits, meat and fish. This type of research has been conducted in Korea (Kim et al. 2019). This could be a purpose for the future research in Lithuania.

\section{References}

Atkinson, L., \& Rosenthal, S. (2014). Signaling the Green sell: the influence of eco-label source, argument specificity, and product involvement on consumer trust. Journal of Advert, (43), 33-45. [Accessed 20.03.2019]. Available from Internet: https://doi.org/10.1080/00913367.2013.834803.

Biswas, A., \& Roy, M. (2015). Green products: an exploratory study on the consumer behaviour in emerging economies of the East. Journal of Cleaner Production, (87), 463-468.

Cerri, J., Testa, F., \& Rizzi, F. (2018). The more I care, the less I will listen to you: how information, environmental concern and ethical production influence consumers' attitudes and the purchasing of sustainable products Journal of Advert, (175), 343-353.

Chekima, B., Oswald, A.I., Wafa, S.A.W.S.K., \& Chekima, K. (2017). Narrowing the gap: factors driving organic food consumption. Journal of Advert, (166), 1438-1447. [Accessed 20.03.2019]. Available from Internet: https://doi.org/10.1016/j.jclepro.2017.08.086.

Costanigro, M., Kroll, S., Thilmany, D., \& Bunning, M. (2014). Is it Love for Local/Organic or Hate for Conventional? Asymmetric Effects of Information and Taste on Label Preferences in an Experimental Auction. Food Quality and Preference, 31(1), 94-105. [Accessed 20.03.2019]. Available from Internet: https://doi.org/10.1016/j.foodqual.2013.08.008

Darnall, N., Ji, H., \& Potoski, M. (2017). Institutional design of ecolabels: sponsorship signals rule strength. Regulations and Governance, (11), 438-450. [Accessed 20.03.2019]. Available from Internet: https://doi.org/10.1111/rego.12166.

Feldmann, C., \& Hamm, U. (2015). Consumers' perceptions and preferences for local food: a review. Food Quality and Preference, (40), 152-164. [Accessed 20.03.2019]. Available from Internet: https://doi.org/10.1016/j.foodqual.2014.09.014.

Filho, E.J.M.A. (2012). Hedonic and social values supporting utilitarian technologies. International Journal of. Innovation and Learning, 12(2), 160-180.

Filho, E.J.M.A., \& Brito, E.P.Z. (2017). Green attributes converged within multifunctional technology products. Telematics and Informatics, (34), 79-90. [Accessed 13.02.2019]. Available from Internet: http://dx.doi.org/10.1016/j.tele.2016.04.008.

Fischer, D., Stanszus, L., Geiger, S., Grossman, P., \& Schrader, U. (2017). Mindfulness and sustainable consumption: a systematic literature review of research approaches and findings. Journal of Cleaner Production, (162), 544-558. [Accessed 20.03.2019]. Available from Internet: https://doi.org/10.1016/j.jclepro.2017.06.007.

Ghali, Z., (2019). The Antecedents of the Consumer Purchase Intention: Sensitivity to Price and Involvement in Organic Product: Moderating Role of Product Regional Identity. Trends in Food Science \& Technology. [Accessed 20.03.2019]. Available from Internet: https://doi.org/10.1016/j.tifs.2019.02.028.

Ha, H., \& Janda, S. (2012). Predicting consumer intentions to purchase energy-efficient products. Journal of Consumer Marketing, (29), 461-469. [Accessed 20.03.2019]. Available from Internet: https://doi.org/10.1108/07363761211274974.

Handriana, T., \& Wisandiko, W.R. (2017). Consumer attitudes toward advertisement and brand, based on the number of endorsers and product involvement: An experimental study. International Journal of Business, 19(3), 
289-306. [Accessed 20.03.2019]. Available from Internet: https://jurnal.ugm.ac.id/gamaijb/article/view/18338/19307

Hüttel, A., Ziesemer, F., Peyer, M., \& Balderjahn, I. (2018). To purchase or not? Why consumers make economically (non-)sustainable consumption choices. Journal of Cleaner Production, (174), 827-836. [Accessed 20.03.2019]. Available from Internet: https://doi.org/10.1016/j.jclepro.2017.11.019.

Joshi \& Rahman, 2019 Joshi, Y., \& Rahman, Z. (2019). Consumers' Sustainable Purchase Behaviour: Modeling the Impact of Psychological Factors. Ecological Economics, (159), 235-243. [Accessed 20.03.2019]. Available from Internet: https://doi.org/10.1016/j.ecolecon.2019.01.025

Kareklas, I., Carlson, J.R., \& Muehling, D.D. (2014). 'I eat organic for my benefit and yours': egoistic and altruistic considerations for purchasing organic food and their implications for advertising strategists. Journal of Advertising, (43), 18-32. [Accessed 20.03.2019]. Available from Internet: https://doi.org/10.1080/00913367.2013.799450.

Kilbourne, W., McDonagh, P., \& Prothero, A., (1997). Sustainable consumption and the quality of life: a macromarketing challenge to the dominant social paradigm. Journal of Macromarketing, 17 (1), 4-24. [Accessed 20.03.2019]. Available from Internet: https://doi.org/10.1177/027614679701700103

Kim, S., Lee, S.K., Jeong, J., \& Moon, J. (2019). The effect of agritourism experience on consumers' future food purchase patterns. Tourism Management, (70), 144-152. [Accessed 20.03.2019]. Available from Internet: https://doi.org/10.1016/j.tourman.2018.08.003

Kytö, E., Virtanen, M. \& Mustonen, S. (2019). From intention to action: Predicting purchase behavior with consumers' product expectations and perceptions, and their individual properties. Food Quality and Preference, (75), 1-9. [Accessed 20.03.2019]. Available from Internet: https://doi.org/10.1016/j.foodqual.2019.02.002

Laureti, T., \& Benedetti, I. (2018). Exploring pro-environmental food purchasing 339 behaviour: An empirical analysis of Italian consumers. Journal of Cleaner Production, (172), 3367-3378. [Accessed 20.03.2019]. Available from Internet: https://doi.org/10.1016/j.jclepro.2017.11.086

Lee, S., Lee, J.-H., \& Garret, T.C. (2013). A study of the attitude toward convergent products: a focus on the consumer perception of functionalities. Journal of Product Innovation Management, 30(1), 123-135.

Liobikiene, G., Grinceviciene, S., \& Bernatoniene, J. (2017). Environmentally friendly behaviour and green purchase in Austria and Lithuania. Journal of Cleaner Production, (142) 3789-3797. [Accessed 20.03.2019]. Available from Internet: https://doi.org/10.1016/j.jclepro.2016.10.084

Lorenz, B.A., Hartmann, M., \& Simons, J. (2015). Impacts from region-of-origin labeling on consumer product perception and purchasing intention - Causal relationships in a TPB based model. Food Quality and Preference, (45), 149-157. [Accessed 20.03.2019]. Available from Internet: https://doi.org/10.1016/j.foodqual.2015.06.002

Montandon, A.C., Ogonowski, A., \& Botha, E. (2017). Product Involvement and the Relative Importance of Health Endorsements. Journal of Food Products Marketing, 23(6), 649-667. [Accessed 20.03.2019]. Available from Internet: $10.1080 / 10454446.2015 .1048031$

Nguyen, T.N., Lobo, A., \& Nguyen, B.K. (2018). Young consumers' green purchase behaviour in an emerging market. Journal of Strategic Marketing, 26 (7), 583-600. [Accessed 20.03.2019]. Available from Internet: https://doi.org/10.1080/0965254X.2017.1318946

Nuttavuthisit, K., \& Thøgersen, J. (2017). The importance of consumer trust for the emergence of a market for Green products: the case of organic food. Journal of Business Ethics, (140), 323-337. [Accessed 20.03.2019]. Available from Internet: https://doi.org/10.1007/s10551-015-2690-5.

Padel, S., \& Foster, C. (2005). Exploring the gap between attitudes and behaviour: understanding why consumers buy or do not buy organic food. British Food Journal, 107(8), 606-625. [Accessed 20.03.2019]. Available from Internet: doi/pdfplus/10.1108/00070700510611002

Park, S. C., \& Keil, M. (2019). The moderating effects of product involvement on escalation behavior. Journal of Computer Information Systems, 59(3), 218-232. [Accessed 20.03.2019]. Available from Internet: https://doi.org/10.1080/08874417.2017.1328648

Popa, M.E., Mitelut, A.C., Popa, E.E., Stan, A., \& Popa, V.L. (2019). Organic foods contribution to nutritional quality and value. Trends in Food Science \& Technology, (84), 15-18. [Accessed 20.03.2019]. Available from Internet: https://doi.org/10.1016/j.tifs.2018.01.003 
Prothero, A., McDonagh, P., \& Dobscha, S. (2010). Is Green the new Black? Reflections on a Green commodity discourse. Journal of Macromarketing, (30), 147-159. [Accessed 20.03.2019]. Available from Internet: https://doi.org/10.1177/0276146710361922

Rahman, I. (2018). The Interplay of Product Involvement and Sustainable Consumption: An Empirical Analysis of Behavioral Intentions Related to Green Hotels, Organic Wines and Green Cars. Sustainable Development, (26), 399-414. [Accessed 20.03.2019]. Available from Internet: https://doi.org/10.1002/sd.1713

Raosoft (2019). Sample size calculator. [Accessed 20.02.2019]. Available from Internet: http://www.raosoft.com/samplesize.html

Sarti, S., Darnall, N., \& Testa, F. (2018). Market segmentation of consumers based on their actual sustainability and health-related purchases. Journal of Cleaner Production, (192), 270-280. [Accessed 20.03.2019]. Available from Internet: https://doi.org/10.1016/j.jclepro.2018.04.188

Schuitema, G., \& de Groot, J.I.M. (2015). Green consumerism: the influence of product attributes and values on purchasing intentions. Journal of Consumer Behaviour, 14(1), 57-69.

Statistics (2018). [Accessed 20.02.2019]. Available from Internet: https://eacea.ec.europa.eu/nationalpolicies/eurydice/content/population-demographic-situation-languages-and-religions-44_lt

Statistics (2019). [Accessed 20.02.2019]. Available from Internet: https://osp.stat.gov.lt/informaciniaipranesimai?articleId=6148505

Verain, M.C.D., Bartels, J., Dagevos, H., Sijtsema, S.J., Onwezen, M.C., \& Antonides, G. (2012). Segments of sustainable food consumers: a literature review. International Journal of Consumer Studies, (36), 123-132. [Accessed 20.03.2019]. Available from Internet: https://doi.org/10.1111/j.1470-6431.2011.01082.x.

Weisstein, F.L., Song, L., Andersen, P., \& Zhu, Y. (2017). Examining impacts of negative reviews and purchase goals on consumer purchase decision. Journal of Retailing and Consumer Services, (39) 201-107. [Accessed 20.03.2019]. Available from Internet: http://dx.doi.org/10.1016/j.jretconser.2017.08.015

Xia, L., \& Monroe, K.B. (2009). The influence of pre-purchase goals on consumers' perceptions of price promotions. International Journal of Retail and Distribution Management, 37(8), 680-694. [Accessed 20.03.2019]. Available from Internet: 10.1108/09590550910966187

Zaichkowsky, J. L. (1985). Measuring the involvement construct. Journal of Consumer Research, 12(3), 341-352. 